ABDIMAS: Jurnal Pengabdian Masyarakat Universitas Merdeka Malang
Vol.6(4) November 2021,512-525
p-ISSN: 2721-138X e-ISSN: 2548-7159
http://jurnal.unmer.ac.id/index.php/jpkm

\title{
Enhancing community creativity through training on making artificial flowers from plastic waste
}

\section{Meningkatkan kreativitas masyarakat melalui pelatihan pembuatan bunga artificial dari limbah plastik}

\author{
Tiara Derawati ${ }^{1}$, Syifaul Fuada ${ }^{2}$ \\ 'Program Studi Pendidikan Guru Sekolah Dasar, ${ }^{2}$ Program Studi Sistem Telekomunikasi, \\ Universitas Pendidikan Indonesia, Kampus Daerah Purwakarta \\ Jl. Veteran No. 8, Purwakarta, 41115, Indonesia
}

\begin{abstract}
ARTICLE INFO
Received: 2021-04-10 Revised: 2021-06-05

Accepted: 2021-07-13

\section{Keywords:}

Artificial flowers, COVID-19, Economics, Plastic waste

\section{ABSTRACT}

The COVID-19 pandemic has a substantial impact on the community, one of which is in the economic sector. Many workers have been laid off, leading to a rise in the unemployment rate in Indonesia. This community service activity aims to help people affected by layoffs as the result of the COVID-19 pandemic through the activities of providing and strengthening functional skills to the community. This online program is a form of Thematic Community Service Program on Prevention and Countermeasure of The COVID-19 Impact. An artificial flower-making training program has been implemented from plastic waste into a work that can increase people's creativity and grow the community's economy. This artificial flower-making training program's target is based on plastic waste in the community from RT/ RW 01/01, Bojong Village, Majalaya, Bandung District, West Java Province. This program was attended by eight people conducted online through WhatsApp Group from December 1 to 10, 2020. In addition to helping the community increase creativity during the COVID-19 pandemic, creating economically valuable communities can indirectly reduce plastic waste in landfills because plastic waste cannot decompose naturally. People who follow this program can sell artificial flowers to improve the economy during the COVID-19 pandemic.
\end{abstract}

(C)2021 Published by University of Merdeka Malang. This is an open access article distributed under the CC BY-SA 4.0 license (https://creativecommons.org/licenses/by-sa/4.0/)

How to cite: Derawati, T., \& Fuada, S. (2021). Enhancing community creativity through training on making artificial flowers from plastic waste. Abdimas: Jurnal Pengabdian Masyarakat Universitas Merdeka Malang, 6(4), 512-525. https://doi.org/10.26905/abdimas.v6i4.5691

\section{PENDAHULUAN}

Hingga saat ini COVID-19 terus memberikan dampak yang signifikan kepada masyarakat dunia, termasuk Indonesia. Salah satu dampak serius yang diakibatkannya adalah pada sektor ekonomi. Terhitung Maret 2020 pemerintah menerapkan Work Form Home (WFH) bagi para pekerja guna memutus rantai persebaran COVID-19 (Kemendikbud, 2020). Sekitar 6,4 juta pekerja yang terpaksa harus dirumahkan dan mendapati PHK karena adanya pandemi COVID-19. Soetrisno selaku Wakil Ketua Kadin 
Bidang Perdagangan mengatakan bahwa keputusan untuk merumahkan atau PHK pekerja merupakan dampak dari menurunnya omset selama pandemi. Tercatat $82 \%$ pengusaha yang mengalami tekanan berat akibat adanya COVID-19. Bahkan UMKM saat ini yang umumnya tahan terhadap gejolak ekonomi juga mendapati tekanan akibat anjloknya pendapatan. Sekitar 48,8\% UMKM harus ditutup sementara, sedangkan 37,9\% lainnya mengalami penurunan penjualan lebih dari 30\% (DDTCNews, 2020). Dengan adanya PHK besar-besaran berdampak juga pada perekonomian masyarakat kecil. Di balik penurunan ekonomi di kalangan masyarakat masih banyak kebutuhan yang harus dipenuhi (Kurniawati \& Fuada, 2021). Dampak tersebut juga dirasakan oleh masyarakat RT/RW 01/01 Desa Bojong Kecamatan Majalaya. Banyak masyarakat yang beralih profesi demi melangsungkan hidup mereka. Meninjau permasalahan tersebut, pelaksana merancang program pengabdian masyarakat untuk mengembangkan kreativitas sekaligus berpotensi untuk memperbaiki ekonomi masyarakat setempat. Kegiatan ini merupakan bagian dari Program KKN-T PPD COVID-19 Universitas Pendidikan Indonesia Tahap II Tahun 2020 yang mana masing-masing peserta KKN wajib menjalankan program di tempat tinggal masing-masing secara mandiri. Program yang diusulkan pengabdi adalah bagaimana memanfaatkan kreativitas barang yang tidak terpakai bisa menjadi suatu karya yang memiliki daya jual. Dalam program ini, pelaksana membuat video tentang cara mengolah sampah plastik menjadi sebuah bunga artificial yang memiliki nilai ekonomi bisa dijual.

Sampah menjadi salah satu masalah bagi masyarakat, begitu banyak sampah yang ditemui di rumah, khususnya sampah plastik. Sampah atau limbah sangat berbahaya jika dibiarkan (Hidayat et al., 2019). Plastik merupakan suatu material yang memiliki banyak manfaat bagi kehidupan tetapi juga dapat membahayakan pada saat yang bersamaan (Hardianti et al., 2017). Plastik sudah menjadi sahabat dekat manusia sekitar satu abad lamanya. Plastik secara terus-menerus diproduksi dan dimanfaatkan hingga sekarang ini (Surtinah et al., 2019). Plastik adalah limbah dari sekian banyak jenis limbah yang sangat sukar untuk diuraikan. Namun, jika dikelola secara benar, sampah tidak hanya mendatangkan bahaya tetapi dapat juga mendatangkan hal positif dan keuntungan (Astuti et al., 2019). Salah satu solusi untuk mengurangi limbah plastik yaitu ketika produk plastik sudah habis masa penggunaannya, maka plastik tersebut dapat memanfaatkannya kembali (Putra \& Yuriandala, 2010). Disisi lain, beberapa kota di Indonesia sudah mulai mengelola sampah plastik menjadi sesuatu yang lebih bernilai dibandingkan dengan menggunakannya kembali, yaitu degan cara mengubahnya menjadi kerajinan tangan (Hidayah et al., 2020), hal ini merupakan suatu solusi yang cukup tepat (Budiarti et al., 2018). Kerajinan yang unik dari limbah plastik adalah selain bermanfaat juga bernilai jual, karena memiliki tekstur dan warna yang begitu beragam, awet, dan tidak berkarat (Susanto et al., 2020). Dengan mengolah limbah plastik bisa membuka peluang usaha bagi masyarakat (Yuliarty \& Anggraini, 2020). Salah satu kerajinan tangan dari limbah plastk yang popular yaitu bunga hias atau bunga artificial. Bunga ini sering dijadikan sebagai dekorasi dalam ruang dan menjadi hiasan dalam acara-acara besar, seperti pernikahan, perayaan ulang tahun, bunga karangan, lamaran, dan lain sebagainya (Tyastuti et al., 2020). Cara pengolahan dan pembuatannya pun relatif mudah, karena siapapun dapat melakukannya. Berkreasi membuat kerajinan bunga dari limbah plastik adalah salah satu kegiatan yang menarik dan dapat meningkatkan kreativitas (Widiyatun \& Wahyuni, 2021), terutama bagi warga yang terdampak ekonomi karena pandemi COVID-19. 
ABDIMAS: Jurnal Pengabdian Masyarakat Universitas Merdeka Malang Volume 6, No. 4, November 2021: 512-525

Karya bunga plastik mampu dimanfaatkan untuk meningkatkan nilai tambah dari pemanfaatan limbah itu sendiri maupun tambahan finansial yang menjanjikan (Hidayat et al., 2021).

Pengabdian pengolahan sampah plastik menjadi sebuah karya pernah dilaksanakan oleh Fauzi. Hasil dari pengabdiannya bahwa dengan cara mengelola sampah plastik dapat merangsang kreativitas dan seni masyarakat (Fauzi et al., 2020). Program serupa juga pernah dilaksanakan oleh Aminudin dan Murwati. Dari kegiatan yang dilakukan dapat mengembangkan keterampilan ibu-ibu PKK dan menghasilkan karya yang bernilai jual tinggi (Aminudin \& Nurwati, 2019). Sejalan juga dengan hasil pengabdian Setiono, bahwa dengan cara membuat kerajinan bunga berbahan dasar plastik dapat megurangi limbah plastik di masyarakat (Setiono et al., 2019). Program-program tersebut dilaksanakan secara tatap muka (offline) sepenuhnya.

Berbeda dengan pada program sejenis diatas, program pengabdian ini menggunakan metode online dalam pelatihan pembuatan bunga bunga artificial dari limbah plastik. Model pelatihan daring dilakukan oleh Widiyatun \& Wahyuni (2021) yang menyampaikan tutorial melaluivideo conference diZoom. Selain itu, disediakan langkah-langkah sistematis melalui media poster. Sementara pada pengabdian ini, pelaksana menggunakan media WhatsApp sepenuhnya selama proses pelatihan berlangsung. Langkah yang dilakukan adalah mengenalkan melalui sebuah video yang dibagikan kepada masyarakat setempat (di sekitar tempat tinggal pengabdi) lewat media sosial grup WhatApp. Selanjutnya, proses pelaksanaan secara mandiri dilakukan oleh masyarakat sasaran dan mereka melaporkan hasilnya di grup WhatsApp khusus yang dibuat. Peserta pelatihan berkonsultasi sepenuhnya lewat grup WhatsApp. Jenis plastik yang digunakan dalam pembuatan bunga artificial ini adalah plastik HDPE (HD) yang biasa digunakan untuk kantong souvenir. Program pengabdian ini bertujuan supaya masyarakat RT/RW 01/01 Desa Bojong, Kecamatan Majalaya, Kabupaten Bandung dapat mengolah limbah sampah menjadi suatu kerajinan yang bernilai ekonomi guna menumbuhkan ekonomi masyarakat yang sedang menurun akibat adanya COVID-19. Disisi lain, program ini merupakan perspektif baru dalam hal pemberian pelatihan fungsional (secara spesifik pelatihan pembuatan bunga artificial) secara online. COVID-19 menyebabkan masyarakat terbatas dalam beraktivitas tatap muka dalam jangka waktu lama, sehingga penggunaan media sosial dalam berinteraksi adalah pilihan tepat sementara ini.

\section{METODE}

Program pelatihan yang merupakan bagian dari KKN-T PPD COVID-19 ini dilaksanakan di RT/ RW 01/01 Desa Bojong, Kecamatan Majalaya, Kabupaten Bandung (peta ditunjukkan pada Gambar 1). Kegiatan dilaksanakan secara simultan selama sepuluh hari, yaitu pada tanggal 30 November hingga 10 Desember 2020. Sebanyak 8 orang masyarakat mengikuti program ini, mereka sebagai peserta pembuatan bunga artificial. Program ini dilaksanakan secara daring dengan video cara membuat bunga dari limbah plastik. Video tersebut kemudian diunggah di kanal YouTube dan dibagikan kepada warga masyarakat melalui grup WhatsApp karena melihat masyarakat sasaran program mayoritas familiar dengan WhatsApp. Pembuatan video pelatihan memproduksi bunga berbahan dasar platik ini melalui beberapa tahapan. 


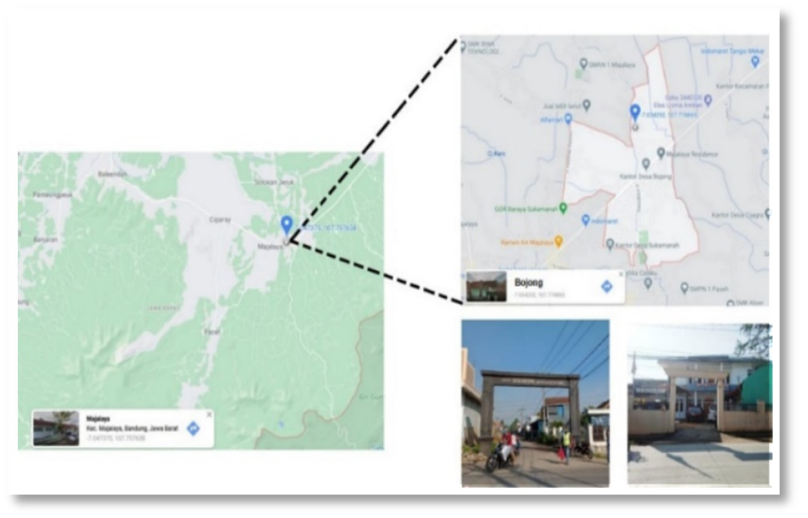

Gambar 1. Lokasi pelaksanaan KKN-T PPD COVID-19, peta Kabupaten Majalaya, Desa Bojong dan gambaran tempat pengabdian

\section{Tahap persiapan}

Pada tahap persiapan pelaksana melakukan tinjauan lapangan mengenai keadaan ekonomi masyarakat sekitar serta melakukan koordinasi bersama RT berkaitan dengan program yang diusulkan pelaksana guna meningkatkan ekonomi masyarakat yang terdampak COVID-19. Selain itu, pelaksana juga berkoordinasi dengan Dosen Pembimbing Lapangan KKN sebelum diselenggarakannya kegiatan ini. Kegiatan selanjutnya adalah mempersiapkan segala sesuatu yang diperlukan pada tahap pelaksanaan seperti mencari bahan untuk pembuatan bunga artificial berbahan dasar plastik.

\section{Tahap pelaksanaan}

Pada tahap pelaksanaan mula-mula pelaksana membuat poster untuk dibagikan kepada grup warga sebagai ajakan untuk membuat kreasi bunga artificial berbahan dasar plastik. Selain itu juga pelaksana membagikan video cara pembuatan bunga artificial berbahan dasar plastik. Setelah video cara pembuatan bunga dibagikan kepada masyarakat, selanjutnya merekrut orang-orang yang tertarik untuk menjadi peserta pembuatan bunga artificial berbahan dasar plastik. Tidak semua masyarakat yang terdampak COVID-19 di desa Bojong tertarik karena beberapa dari mereka memilih untuk mengembangkan kreativitas lain (selain program yang ditawarkan). Sehingga peserta yang berhasil di-hire dari program ini sangat terbatas. Pelaksanaan pelatihan sepenuhnya dilakukan secara online melalui media grup WhatsApp karena pihak UPI mengharuskan segala bentuk program pengabdian yang dijalankan harus dalam jaringan. UPI tidak mengijinkan semua peserta KKN untuk bertatap muka dengan masyarakat dalam durasi waktu yang lama guna mencegah cluster COVID-19 yang baru kerena saat itu kasus positif COVID-19 di Bandung dan sekitarnya relatif sangat tinggi.

Tahap selanjutnya yaitu melaksanakan diskusi terkait kreasi yang akan dibuat, setiap orang bebas untuk berkreasi sesuai dengan imajinasi masing-masing. Alat dan bahan disediakan oleh pelaksana. Kemudian masuk tahap proses pembuatan dimana mereka melakukan praktik pembuatan bunga artificial secara mandiri di rumah masing-masing guna menghindari kerumunan. Sementara itu proses 
ABDIMAS: Jurnal Pengabdian Masyarakat Universitas Merdeka Malang

Volume 6, No. 4, November 2021: 512-525

pelaksanaannya dilaporkan melalui grup WhatsApp. Pelaksana selalu memantau kemajuan kegiatan dari para peserta yang mengikuti program.

\section{Tahap evaluasi}

Pada tahap evaluasi pelaksana melakukan wawancara kepada beberapa masyarakat tentang program yang dilaksanakan. Wawancara dilakukan secara virtual melalui WhatsApp Chat maupun WhatsApp Call. Selain wawancara, pelaksana juga melakukan evaluasi melalui Google Form yang diisi oleh masyarakat. Evaluasi hanya sebatas untuk mengetahui bagaimana respon mereka terhadap program KKN dari pelaksana.

\section{HASIL DAN PEMBAHASAN}

Seperti yang telah disebutkan pada bagian pendahuluan bahwa pada kegiatan KKN ini, program yang dilakukan oleh pelaksana pertama kali adalah membuat video cara membuat bunga artificial dari limbah plastik. Beberapa alat dan bahan yang digunakan perlu disiapkan, diantaranya limbah plastik dalam bentuk kresek belanja, kawat, selotip, lem tembak, gunting, dan tang, seperti yang ditunjukkan pada Gambar 2.
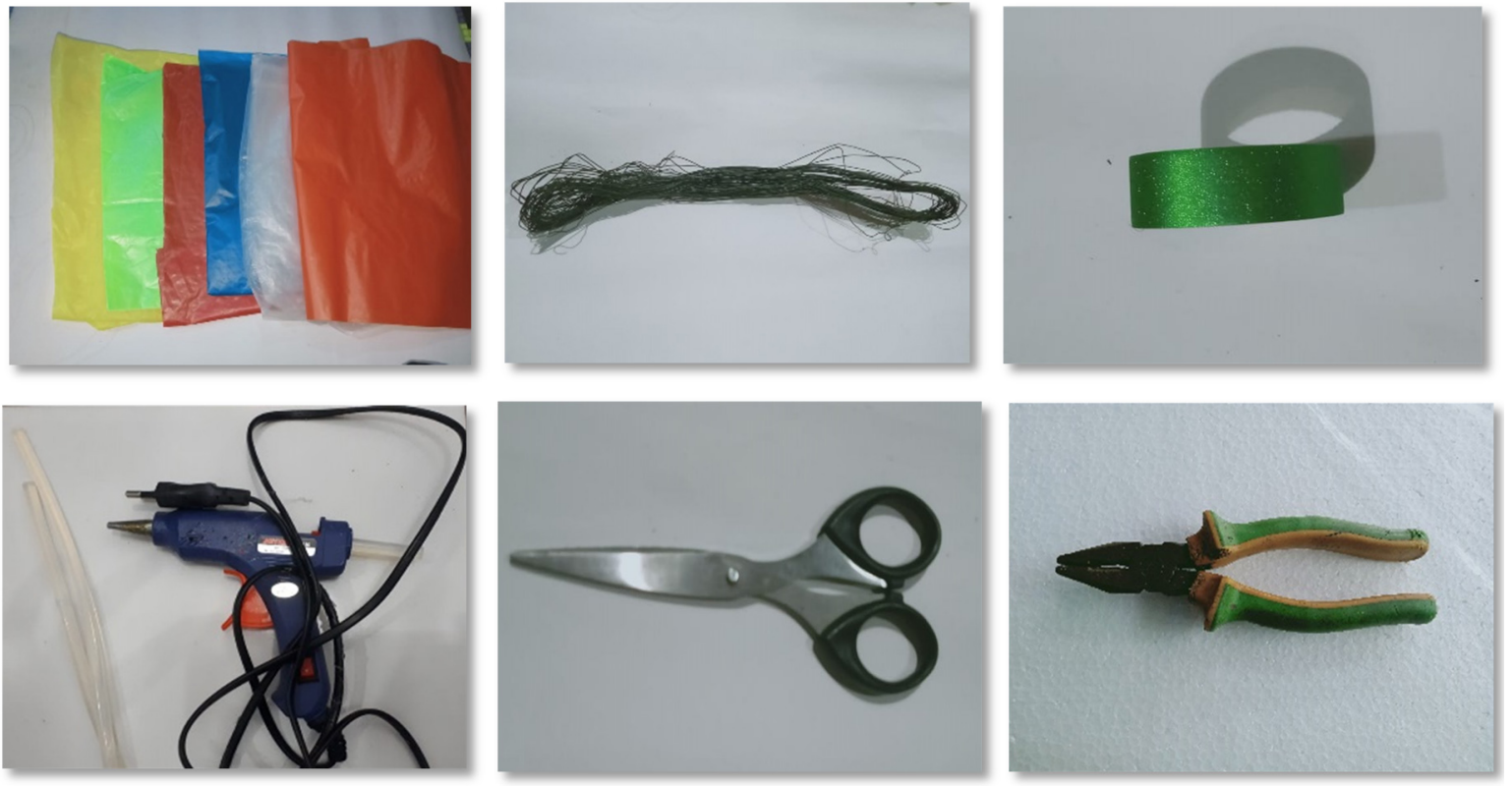

Gambar 2. Alat dan bahan pembuatan bunga artificial: (a) Plastik, (b) Kawat, (c) Selotip warna hijau,

(d) Lem dan alat lem tembak, (e) Gunting, (f) Pemotong kawat

Bahan-bahan tersebut sebagian menggunakan bahan yang tersedia dan memanfaatkan plastik tidak terpakai, sisanya membeli seperti plastik berwarna merah dan orange. Adapun cara pembuatan bunga artificial ini adalah dengan cara memotong plastik (kresek) mejadi 4 bagian dengan ukuran 15×30 
$\mathrm{cm}$. Selanjutnya, ujung plastik kresek yang telah disatukan dijepit menggunakan binder klip agar tidak berubah posisinya. Plastik yang telah dijepit kemudian dilipat ke atas dan ke bawah selebar $1 \mathrm{~cm}$ sampai habis menyerupai dasi kupu-kupu, kemudian binder klip dilepas. Plastik yang telah menyerupai kupukupu dijepit bagian tengahnya menggunakan kawat sampai kencang, kawat dibiarkan panjang ke arah bawah sebagai tangkai bunga. Setelah itu ujung plastik kresek yang telah dibentuk menyerupai dasi kupu-kupu dipotong hingga rapi. Setelah itu lipatan plastik dibuka lembar demi lembar hingga mekar dan menyerupai bunga. Untuk daunnya, memakai plastik berwarna hijau tua yang dibentuk menyerupai daun kemudian dilipat-lipat agar menyerupai akar daun. Setelah itu, kawat ditutup menggunakan selotip berwarna hijau sehingga menyerupai tangkai bunga dan direkatkan dengan daun menggunakan lem. Agar terlihat lebih indah, bunga dari plastik kresek yang telah jadi tersebut kemudian disimpan dalam suatu pot dengan busa sebagai tempat menancapkan bunga.

Setelah mengambil video cara membuat bunga dari plastik kresek kemudian video diedit dan dipublikasikan di kanal Youtube, berikut link yang dapat diakses: https://youtu.be/gl-wGgISzRo, seperti yang ditampilkan pada Gambar 3. Video ini telah mendapatkan pengakuan Hak Cipta dari Kemhumkam Direktorat HKI Repulik Indonesia, dengan judul "Video Pendek Cara Pembuatan Bunga Artificial Berbahan Dasar Plastik Untuk Warga Desa Bojong yang Terdampak COVID-19", jenis HKI adalah rekaman video dengan nomor registrasi dan pencatatan EC00202101690/000233160 atau dapat diakses di https:// pdki-indonesia.dgip.go.id/detail/EC00202101690?type = copyright\&keyword=Video + Pendek + Cara + Pe mbuatan+Bunga+Artificial+Berbahan+Dasar+Plastik+Untuk+Warga+Desa+Bojong +Yang+Terdampak +COVID-19.

Selain membuat video, pelaksana juga membuat poster seperti yang diilustrasikan pada Gambar 4, sebagai pemberitahuan dan ajakan kepada masyarakat untuk membuat bunga artificial. Poster dibuat berdasarkan hasil bimbingan dengan DPL. Tautan video Youtube dan poster dibagikan kepada masyarakat RT/RW 01/01 melalui grup WhatsApp sebagai bentuk ajakan sekaligus motivasi agar masyarakat mau mencoba untuk berkreasi saat pandemi COVID-19 dalam hal pemanfaatan limbah plastik menjadi bunga estetik yang layak jual, seperti yang disajikan pada Gambar 5. Respon masyarakat terhadap program ini cukup baik. Beberapa masyarakat tertarik untuk mengikuti program dengan durasi cukup lama, yaitu 10 hari. Kegiatan berlangsung ke tahap diskusi pembuatan bunga artificial pada grup WhatsApp baru yang khusus untuk media pelatihan. Grup WhatsApp ini beranggotakan sembilan orang, yaitu pelaksana dan delapan peserta lainnya, dimana para peserta berusia produktif (antara 20 hingga 35 tahunan). Namun, meskipun cukup banyak orang yang berminat ternyata tidak semua mendaftar program pelatihan ini dengan alasan mereka tidak memiliki waktu banyak karena pelaksanaannya mandiri dengan kreativitas masing-masing dan harus meninjau secara simultan di grup WhatsApp khusus.

Bahan dasar disediakan oleh pengabdi dan diberikan secara gratis kepada para peserta kegiatan, kecuali alat-alat pendukung seperti tang dan gunting. Masing-masing peserta dikoordinasikan lewat WhatsApp untuk menyediakan beberapa limbah plastik yang relatif masih baru (fresh) sebelum pelatihan dimulai. Pengabdi meminjamkan lem tembak kepada para peserta yang dapat digunakan untuk merekatkan antar material. Peserta pembuatan bunga artificial kemudian berdiskusi untuk menyampaikan ide pembuatan bunga artificial berbahan dasar plastik dengan model berbeda. Proses diskusi dilaksanakan di grup WhatsApp (Gambar 5) dalam jangka waktu pelatihan, yaitu dari tanggal 1 
ABDIMAS: Jurnal Pengabdian Masyarakat Universitas Merdeka Malang Volume 6, No. 4, November 2021: 512-525

hingga 10 Desember 2020. Selain itu juga, peserta yang sudah berhasil membuat bunga melampirkan bukti berupa foto di grup WhatsApp (Gambar 6) sebagai laporan.
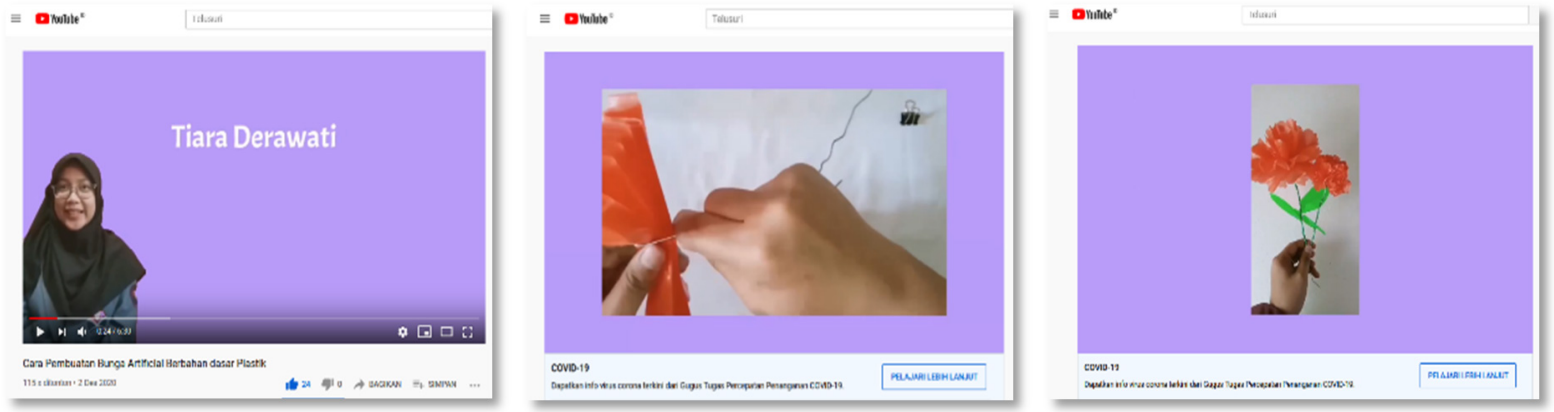

Gambar 3. Video cara pembuatan bunga artificial berbahan dasar plastik yang berdurasi 6 detik 30 detik berisi tentang tutorial singkat cara pembuatan bunga artificial berbahan dasar plastik, memuat pembukan, proses pembuatan, dan hasil jadi

Meskipun program ini dilaksanakan secara online di grup WhatsApp, ternyata program berjalan sesuai rencana. Hal ini dibuktikan dengan munculnya potensi-potensi yang dimiliki oleh warga lokal (sebanyak 8 orang) yang mengikuti program. Gambar 7 merupakan hasil kreasi bunga artificial yang berhasil diciptakan oleh masyarakat sasaran program dalam durasi kurang lebih selama sepuluh hari. Berdasarkan tinjauan, karya yang dibuat memiliki estetika atau daya tarik yang baik, rapi, dan berpotensi untuk menghasilkan keuntungan di masa pandemi COVID-19 karena hasil karyanya memiliki nilai jual. Dari dokumentasi foto pada Gambar 7 dapat dilihat bahwa masing-masing bunga berbeda satu sama lain menandakan kreativitas berhasil dikembangkan oleh masing-masing peserta melalui pelatihan online ini.

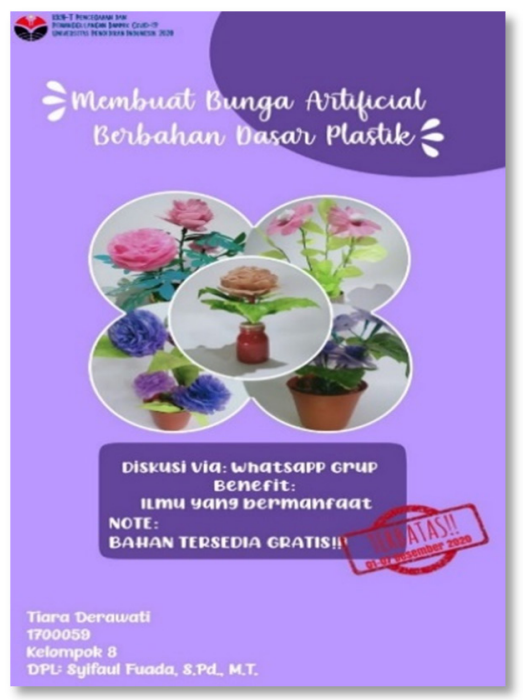

Gambar 4. Poster pelatihan pembuatan bunga artificial berbahan dasar limbah plastik 

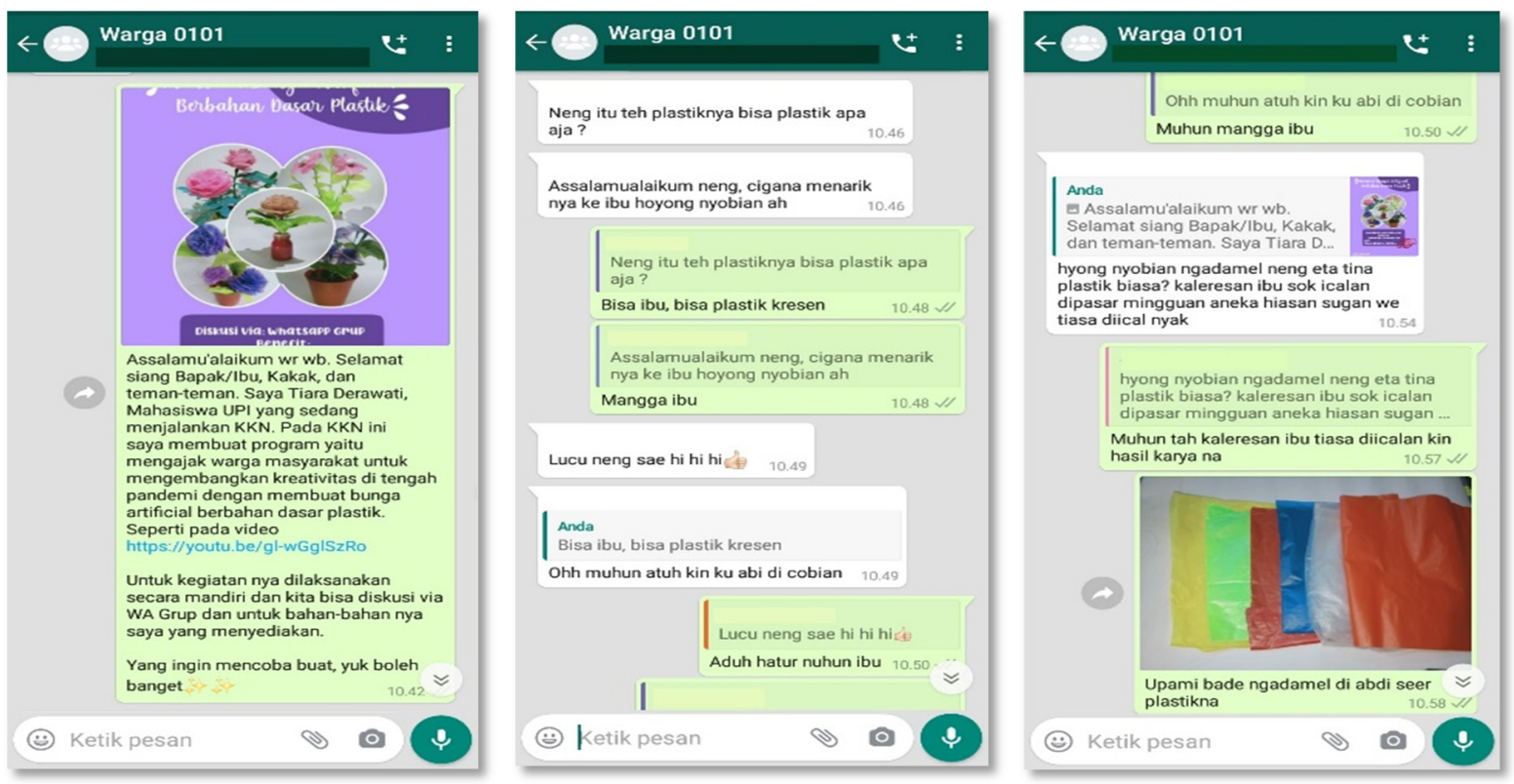

Gambar 5. Pembagian poster dan tautan video tutorial yang telah dibuat di grup WhastApp desa, respon masyarakat terhadap program, lanjutan respon masyarakat

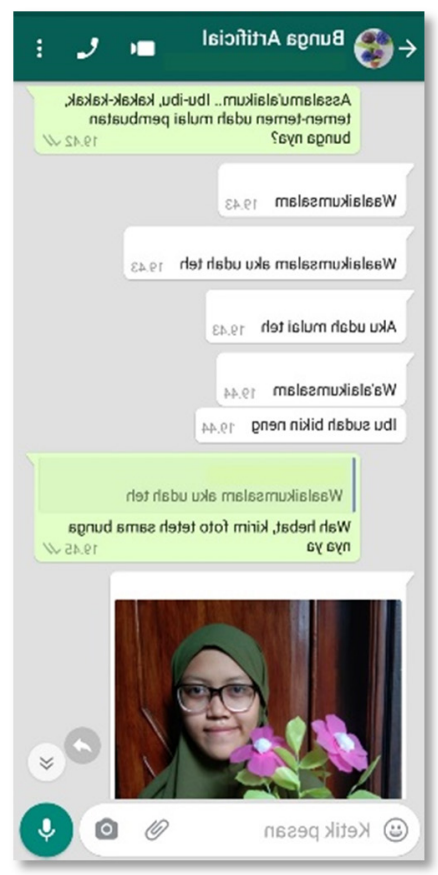

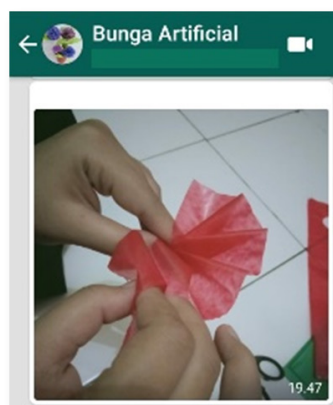

a 6
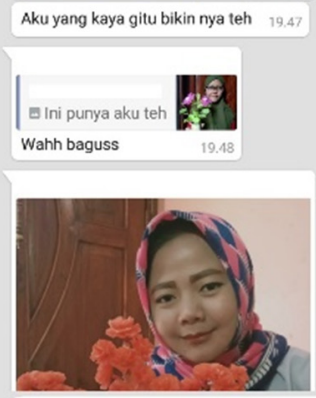

(2) 0

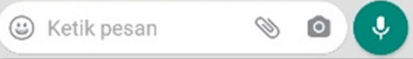

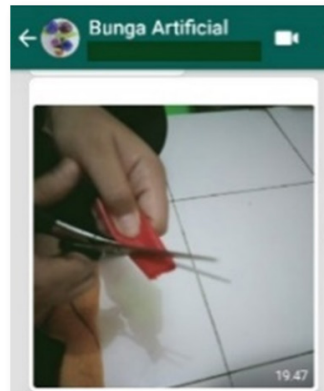

- 6

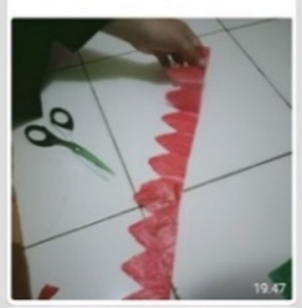

$\odot$

$\odot$

(:) Ketik pesan

\& 
ABDIMAS: Jurnal Pengabdian Masyarakat Universitas Merdeka Malang Volume 6, No. 4, November 2021: 512-525
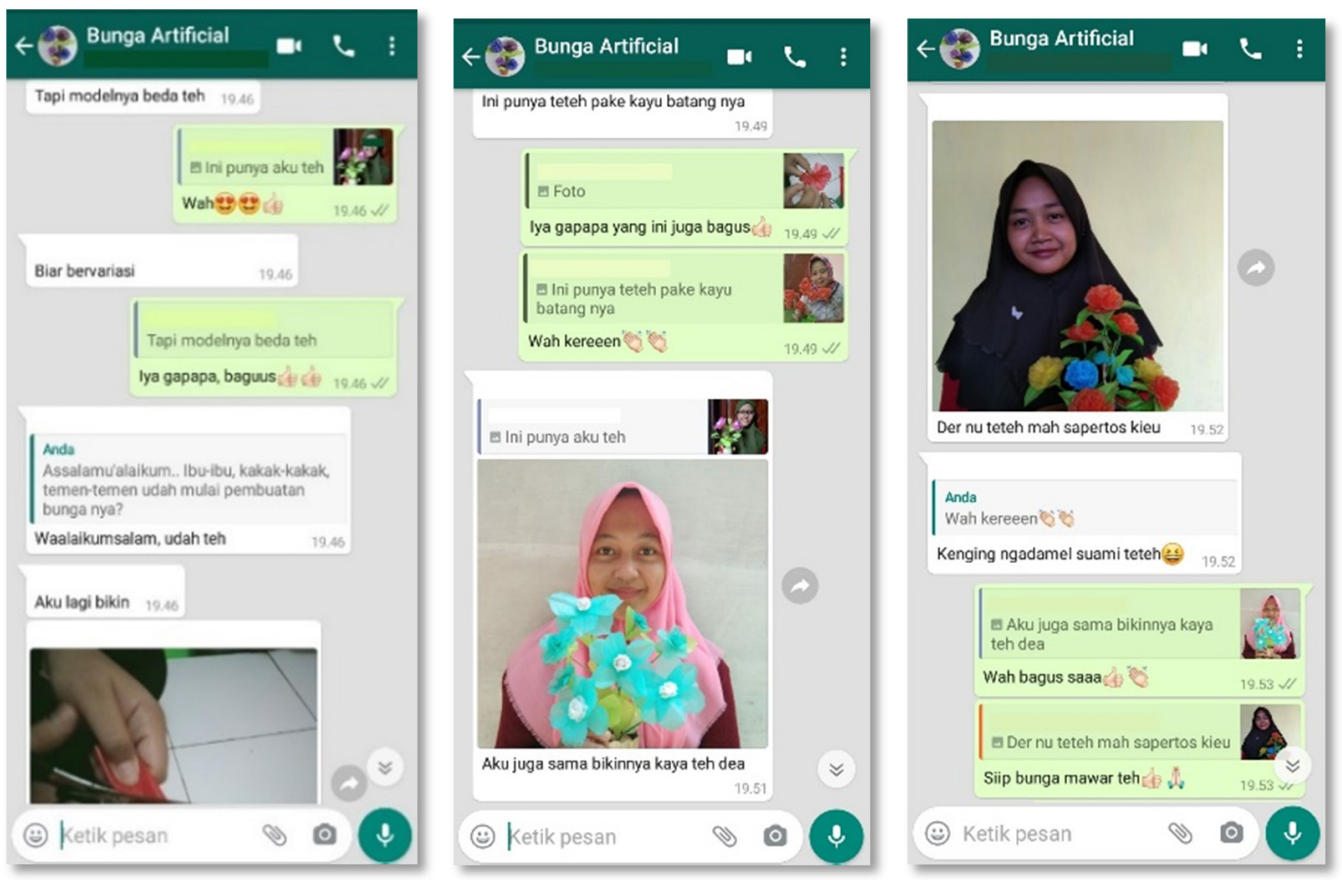

Gambar 6. Proses diskusi dan laporan hasil kreasi masyarakat (sampel screen shoot dari grup WhatsApp)
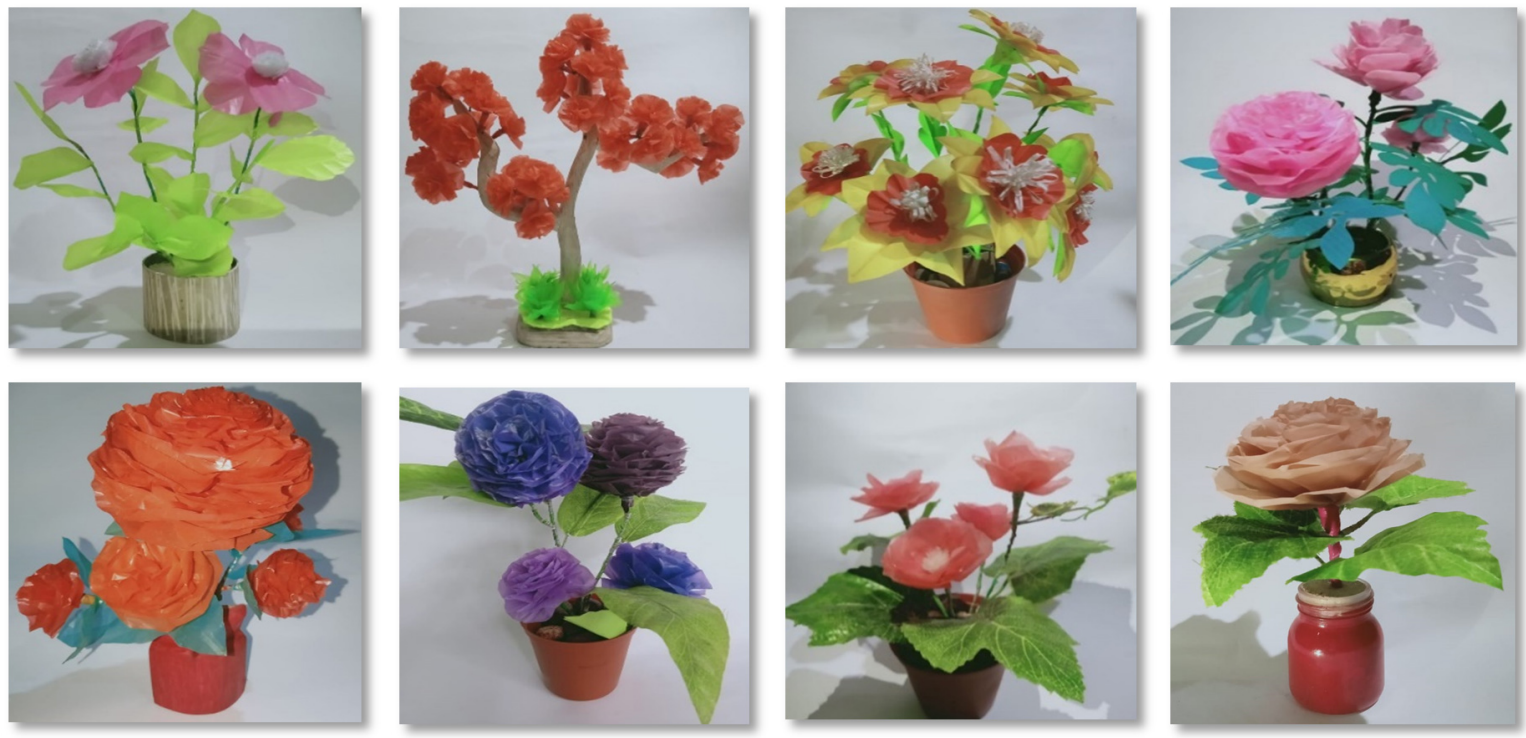

Gambar 7. Aneka bunga artificial hasil kreasi masyarakat setelah pelatihan secara daring, bunga disimpan pada pot yang disediakan oleh masing-masing peserta

Aktivitas diskusi, pendampingan, laporan kemajuan karya secara online di grup WhatsApp berjalan lancar karena WhatsApp merupakan media utama komunikasi masyarakat setempat sehingga tidak ada kesulitan. Selama pelatihan dalam pantauan pelaksana, peserta merasa rileks dalam berinteraksi satu 
sama lainnya secara maya, karena interaksi di grup WhatsApp dapat dilakukan dimana saja dan kapan saja dalam jangka waktu pelatihan. Selain sebagai alternatif media belajar di masa Pandemi COVID-19 (Kurnia \& Fuada, 2021), WhatsApp bahkan dapat dimanfaatkan sebagai media pelatihan (Latipah \& Fuada, 2021), terutama kegiatan pendampingan bagi masyarakat dalam rangka memberikan pengetahuan dan hobi baru atau membekali kreativitas baru yang prospektif, seperti halnya pelatihan bunga artificial ini.

Platform pesan instan ini ringan diakses dan hemat kuota, terhubung otomatis dengan nomor telepon seluler, tidak memerlukan mekanisme yang rumit dalam mengundang para peserta untuk bergabung di grup, menyediakan fitur berkirim lokasi, pesan suara, foto, dan dokumen baik secara personal atau di grup yang telah dibuat, dapat meneruskan pesan broadcast atau pribadi, beragam pilihan emoticon atau meme bergerak sehingga suasana diskusi menjadi lebih hidup, dan berbagai fitur lain. Peserta pelatihan tidak ada kesulitan dalam mengirimkan foto kemajuan karena didukung oleh literasi teknologi informasi dan komunikasi (TIK) yang baik dan jaringan internet yang memadahi di Desa Bojong. Fitur WhatsApp dilengkapi dengan pengecekan apakah pesan di grup sudah dibaca atau belum oleh anggota-anggotanya sehingga peserta yang partisipasinya pasif dapat dideteksi dengan mudah. Berdasarkan pengamatan secara berkala selama pelatihan online, pelaksana menemukan bahwa hampir setiap pesan yang dikirimkan telah dibaca oleh para peserta di grup. Artinya, para peserta pelatihan berpartisipasi aktif dalam mengikuti diskusi meskipun tidak selalu merespon dengan mengirim pesan kembali.

\section{Evaluasi}

Untuk mengetahui respon masyarakat mengenai program yang dilakukan, pelaksana melakukan wawancara terhadap beberapa masyarakat yang dilaksanakan secara daring melalui WhatsApp dan Google Form yang diisi oleh masyarakat. Google Form digunakan untuk mengetahui tingkat pemahaman setelah mengikuti pelatihan. Sedangkan wawancara melalui WhatsApp dilaksanakan untuk mendapatkan tanggapan dan saran dari peserta. Tabel 1 merupakan data yang didapatkan dari Google Form. Pertayataan dari form yang disediakan hanya mengukur satu parameter saja, yaitu tingkat pemahaman. Sementara tingkat kegagalan setiap proses dengan data kuantitatif tidak dilakukan. Form menggunakan skala Likert 1 - 4, yaitu Sangat Paham (4), Paham (3), Tidak Paham (2), Sangat Tidak Paham (1). Hasil menunjukkan bahwa $62,5 \%$ dari delapan peserta pelatihan sangat paham dan sisanya menjawab cukup paham (37,5\%). Dalam hal ini tidak ada peserta yang mengisi "2" atau "1". Video pendek yang telah dibuat oleh pelaksana mendukung terlaksananya program, sehingga peserta mudah memahami langkah-langkah yang diberikan dengan menggunakan alat dan bahan yang disediakan. Pembuatan bunga artificial dari limbah plastik dinilai mudah bagi masyarakat sasaran program.

Tabel 1. Tingkat pemahaman masyarakat terhadap program

\begin{tabular}{cc}
\hline Aspek & Persentase \\
\hline Cukup Paham & 37,5 \\
Sangat Paham & 62,5 \\
\hline
\end{tabular}


ABDIMAS: Jurnal Pengabdian Masyarakat Universitas Merdeka Malang

Volume 6, No. 4, November 2021: 512-525

Berikut adalah beberapa tanggapan masyarakat mengenai program yang dilaksanakan: "Ide pemanfaatan limbah plastik menjadi suatu karya yang bernilai jual itu sangat bagus." (D.S., 20 tahun, Ungkapan Peserta 1), "Bunga yang dihasilkan sangat bagus, banyak orang yang tertarik dengan bunga dari plastik, semoga ini bisa menjadi bisnis yang berkembang di masyarakat kita." (E.M., 22 tahun, Ungkapan Peserta 2). "Idenya bagus, lebih baik lagijika diadakan sosialisasi dan pelatihan cara pembuatannya secara langsung supaya kreativitas masyarakat juga terus berkembang." (N.Z., 21 tahun, Ungkapan Peserta 3). "Jika saja kegiatannya dilaksanakan secara langsung, bukan daring melalui video pasti banyak warga yang antusias untuk melihat cara membuatan bunga karena hasil karyanya bagus-bagus." (W.W., 27 tahun, Ungkapan Peserta 4). "Ternyata limbah plastik keresek bisa dimanfaatkan menjadi kerajinan yang hasilnya bagus ya. Bunganya tidak terlihat seperti dari plastik." (S.M., 32 tahun, Ungkapan Peserta 5). "Kreatif sekali, limbah plastik bisa dijadikan sebagai kerajinan tangan yang bernilai jual." (S.R., 30 tahun, Ungkapan Peserta 6). "Kegitan ini bagus jika terus berlanjut. Bisa meningkatkan ekonomi masyarakat." (N.K., 27 tahun, Ungkapan Peserta 7). "Hasilnya bagus, pembuatannya mudah diikuti." (A.K., 35 tahun, Ungkapan Peserta 8).

Respon masyarakat sangat antusias dan saran dari masyarakat yang dapat dijadikan masukan positif oleh pelaksana bahwa dengan adanya pelatihan secara langsung bisa menjadi lebih efektif dengan jumlah peserta yang lebih banyak. Namun, aturan KKN dari kampus pelaksana membatasi kegiatan yang dijalankan ini. Menurut pelaksana, pelatihan secara daring ini justru sebenarnya lebih fleksibel karena dapat dikerjakan kapan saja atau saat senggang dalam durasi waktu pelatihan serta lebih hemat tenaga karena tidak perlu datang ke tempat pelatihan. Apabila kegiatan ini berkelanjutan, maka bisa menjadi peluang usaha baru bagi masyarakat. Pengolahan limbah plastik dapat menjadi solusi kreatif guna memberantas kemiskinan (Banowati, 2014). Bunga artificial ini bisa menjadi suatu produk yang diminati di kalangan masyarakat tertentu.

\section{Faktor pendukung dan penghambat}

Salah satu faktor pendukung program ini yaitu adanya respon dari beberapa masyarakat yang antusias ketika melihat video cara pembuatan bunga artificial dari bahan limbah plastik kresek yang dibagikan lewat grup WhatsApp. Masyarakat yang tertarik mengikuti pelatihan daring memiliki waktu yang luang dimasa pandemi ini, sehingga lebih baik dimanfaatkan untuk meningkatkan kreativitas. Mayoritas masyarakat RT/RW 01/01, Desa Bojong, Kecamatan Majalaya, Kabupaten Bandung, Jawa Barat hobi mengoleksi bunga asli yang dipelihara di lingkungan tempat tinggal mereka, sehingga menambah motivasi sekaligus memiliki gambaran tentang bunga yang akan dikembangkan. Dengan demikian, secara kondisi masyarakat, kreativitas dan potensinya sudah siap untuk dikembangkan. Faktor pendukung lainya adalah bahan-bahan untuk pembuatan yang mudah ditemukan di sekitar masyarakat bahkan bahan dasar (limbah kresek) telah menjadi sahabat akrab bagi warga RT/RW 01/01, Desa Bojong, karena setiap aktivitas belanja selalu mendapati plastik dari jenis kresek yang baru.

Namun, program sedikit memiliki hambatan yaitu kurangnya media yang digunakan untuk melakukan sosialisasi pelatihan, karena ternyata tidak sedikit juga warga sekitar yang belum mengenal 
media sosial, seperti WhatsApp. Sementara itu, warga yang telah menggunakan layanan WhatsApp beberapa orang merasa tidak sanggup mengikuti pelatihan karena keterbatasan waktu dan merasa kurang efektif jika dilaksanakan secara online.

\section{SIMPULAN DAN SARAN}

Penanggulangan dampak COVID-19 di bidang ekonomi dengan cara meningkatan kreativitas masyarakat agar mampu mengolah limbah plastik menjadi suatu karya yang bernilai ekonomi dinilai cukup efektif. Meskipun pelaksanaan program di grup WhatApp saja yang cukup terbatas dalam hal interaksi, ternyata tetap mampu menumbuhkan kreativias masyarakat sasaran dalam menghasilkan bunga artificial yang memiliki estetika yang relatif baik. Hasil dari program ini menciptakan perspektif baru dalam pemberian pelatihan yang diselenggarakan oleh civitas akademika karena secara sepenuhnya memanfaatkan media sosial mulai dari koordinasi sebelum kegiatan hingga evaluasi program. Hasil kreasi masyarakat dari program ini berpotensi membuka peluang usaha baru dari mereka. Selain itu, secara tidak langsung program ini sebagai bentuk usaha untuk mengurangi sampah plastik di lingkungan masyarakat.

Sebaiknya program pelatihan pembuatan bunga artificial berbahan dasar plastik ini dilaksanakan dalam waktu yang lebih lama dan terus berlanjut karena melihat respon positif dari masyarakat. Dengan demikian, tidak hanya sebatas membuat atau menyalurkan kreativitas saja melainkan mampu melihat kesempatan untuk dipasarkan secara langsung maupun online. Pelaksana dapat menyediakan platform khusus untuk penjualan online seperti media sosial (Instagram, Facebook, Twitter, dan lain sebagainya), website/weblog atau berbasis e-commerce sehingga kreativitas masyarakat setempat dalam membuat bunga plastik dapat dikonversikan menjadi keuntungan finansial secara nyata. Untuk penggunaan e-commerce, perlu dilakukan pelatihan dan pendampingan tahap berikutnya. Agar dapat memanfaatkan sampah plastik secara optimal, pot bunga artificial hendaknya juga terbuat dari sampah plastik, misalnya botol plastik yang dipotong dan dihias menarik. Selain itu, program perlu ditindaklanjuti terutama dibagian evaluasi sehingga pelaksana mengetahui lebih jauh adanya perubahan perilaku masyarakat dilihat dari perbandingan sebelum dan setelah pelatihan. Selain mengukur tingkat pemahaman, pelaksana pengabdian masyarakat perlu mengukur proses pelatihan ditinjau dari tingkat kegagalan pada setiap tahapan

\section{UCAPAN TERIMA KASIH}

Pelaksana mengucapkan banyak terima kasih kepada LPPM Universitas Pendidikan Indonesia (UPI) yang telah mendukung kegiatan pelatihan ini melalui KKN-T PPD COVID-19. Ucapan terima kasih disampaikan kepada Ketua RT dan RW 01/01 yang telah memberi ijin sehingga program dapat terselenggara dengan lancar. Terakhir, terima kasih kepada redaksi media massa www.ayobandung.com yang telah menerbitkan berita dari program ini. Berita bisa diakses di https://ayobandung.com/read/2020/12/16/164014/ mahasiswa-upi-purwakarta-kenalkan-cara-pembuatan-bunga-artificial-berbahan-dasar-plastik. 
ABDIMAS: Jurnal Pengabdian Masyarakat Universitas Merdeka Malang

Volume 6, No. 4, November 2021: 512-525

\section{DAFTAR PUSTAKA}

Aminudin, \& Nurwati. (2019). Pemanfaatan sampah plastik menjadi kerajinan tangan guna meningkatkan kreatifitas warga sekitar Institut Teknologi dan Bisnis Ahmad Dahlan (ITB-AD) Jakarta. Jurnal Abdimas BSI: Jurnal Pengabdian Kepada Masyarakat, 2(1). https://doi.org/10.31294/jabdimas.v2i1.4515

Astuti, I. P., Buntoro, G. A., \& Ariyadi, D. (2019). Pelatihan pemanfaatan barang bekas untuk pembuatan buket bunga dan cara pemasarannya. Warta LPM, 21(2), 6-10. https://doi.org/10.23917/warta.v21i2.7739

Banowati, E. (2014). Pengentasan kemiskinan penduduk perkotaan melalui pelatihan pengolahan sampah. Komunitas: International Journal of Indonesian Society and Culture, 6(1), 159-169. https://doi.org/10.15294/komunitas.v6i1.2944

Budiarti, W., Susilowati, S., \& Farida, I. (2018). Upaya pemanfaatan sampah plastik Kelompok IbuIbu Dasawisama Gladiol 161 di Perumahan Magersari Permai, Kabupaten Sidoarjo. Jurnal Komunikasi Profesional, 2(2), 13. http://dx.doi.org/10.25139/jkp.v2i2.1377

DDTCNews. (2020). Kadin: 6,4 juta pekerja dirumahkan atau di-PHK akibat Corona. DDTCNews. https://news.ddtc.co.id/kadin-64-juta-pekerja-dirumahkan-atau-di-phk-akibat-corona-24551

Fauzi, M., Sumiarsih, E., Adriman, A., Rusliadi, R., \& Hasibuan, I. F. (2020). Pemberdayaan masyarakat melalui pelatihan pembuatan ecobrick sebagai upaya mengurangi sampah plastik di Kecamatan Bunga Raya. Riau Journal of Empowerment, 3(2), 87-96. https://doi.org/10.31258/raje.3.2.87-96

Hardianti, D., Abas, T., \& Ningsih, M. P. (2017). Persepsi kader PKK tentang daur ulang limbah plastik berbasis home industry di Desa Cilame Kabupaten Bandung Barat. FamilyEdu: Jurnal Pendidikan Kesejahteraan Keluarga, 3(2), 73-79.

Hidayah, D. U., Utami, D. A. B., Tripustikasari, E., Sholikhatin, S. A., Subarkah, P., \& Putra, R. N. D. (2020). Pemanfaatan limbah plastik menjadi kerajinan tangan menggunakan video tutorial bagi Ibu-Ibu PKK Desa Rabak, Kecamatan Kalimanah, Kabupaten Purbalingga. JPMB: Jurnal Pemberdayaan Masyarakat Berkarakter, 3(1), 17-25.

Hidayat, N. F., Zainollah, M., \& Oktaviani, D. (2019). Pemanfaatan sampah plastik menjadi kerajinan rumah tangga untuk meningkatkan kesejahteraan warga Pengos-A Gerbosari Samigaluh Kulon Progo. Prosiding Konferensi Pengabdian Masyarakat, 1(4), 101-104.

Hidayat, R., Luktiana, Y.F., \& Anisa, R. (2021). Pendampingan pemanfaatan sampah plastik menjadi produk yang memiliki nilai tambah. Jurnal Ilmiah Pengabdian Kepada masyarakat (PAKEM), $3(1), 151-158$.

Kementerian Pendidikan dan Kebudayaan (Kemendikbud). (2020, March 17). Kemendikbud terapkan bekerja dari rumah bagi ASN Kantor Pusat. Kementerian Pendidikan dan Kebudayaan.

https://www.kemdikbud.go.id/main/blog/2020/03/kemendikbud-terapkan-bekerja-darirumah-bagi-asn-kantor-pusat

Kurnia, S., \& Fuada, S. (2021). Program penguatan pembelajaran online di PAUD RA Daarul Amiin Purwakarta pada masa pandemi COVID-19. J-ABDIPAMAS (Jurnal Pengabdian Kepada Masyarakat), 5(1), 165-178. http://dx.doi.org/10.30734/j-abdipamas.v5i1.1736

Kurniawati, R., \& Fuada, S. (2021). Pendampingan bisnis online model droshipping guna pemulihan ekonomi akibat pandemi COVID-19 pada Masyarakat Kampung Dayeuhkolot-Subang. Jurnal Pengabdian Masyarakat IPTEKS, 7(2). 


\section{Enhancing community creativity through training on making artificial flowers from plastic waste}

Tiara Derawati, Syifaul Fuada

Latipah \& Fuada, S. (2021). Pelatihan Kinemaster bagi guru TK Sekarwangi Cirebon untuk meningkatkan literasi dalam pembuatan video pembelajaran daring. J-ABDIPAMAS (Jurnal Pengabdian Kepada Masyarakat), 5(1), 101-112. http://dx.doi.org/10.30734/j-abdipamas.v5i1.1696

Putra, H. P., \& Yuriandala, Y. (2010). Studi pemanfaatan sampah plastik menjadi produk jasa kreatif. Jurnal Sains dan Teknologi Lingkungan, 2(1), 21-31. https://doi.org/10.20885/jstl.vol2.iss1.art3

Setiono, I., Kusumayanti, H., Dwimawanti, I. H., Aryani, Z., \& Soedharto, J. (2019). Pelatihan pembuatan bunga artificial dari sampah plastik kresek di Desa Kangkung, Kecamatan Mranggen, Kabupaten Demak. Jurnal Pengabdian Vokasi, 01(02), 116-118.

Surtinah, S., Lidar, S., \& Wulantika, T. (2019). Daur ulang botol plastik menjadi bunga imitasi pada kelompok remaja di lingkungan Kampus Unilak. SYUKUR (Jurnal Inovasi Sosial dan Pengabdian Masyarakat), 2(1), 37. https://doi.org/10.22236/syukur_vol2/is1pp37-46

Susanto, A., Putranto, D., Hartatadi, H., Luswita, L., Parina, M., Fajri, R., Sitiana, S., Septiara, S., \& Amelinda, Y. S. (2020). Pemberdayaan masyarakat melalui pengelolaan sampah dalam mengurangi sampah botol plastik kampung nelayan Kelurahan Tanjung Ketapang. Abdi: Jurnal Pengabdian dan Pemberdayaan Masyarakat, 2(2), 94-102. https://doi.org/10.24036/abdi.v2i2.49

Tyastuti, R. O. W., \& Puspitorini, A. (2020). Pemanfaatan limbah plastik low-density polytehylene sebagai daur ulang pembuatan bunga artifisial untuk dekorasi ruangan salon kecantikan. Jurnal Tata Rias, 9(2), 317 - 324.

Yuliarty, P., \& Anggraini, R. (2020). Pelatihan membuat produk kerajinan kreatif dari sampah kantong plastik. Abdimas: Jurnal Pengabdian Masyarakat Universitas Merdeka Malang, 5(3), 279-285. https://doi.org/10.26905/abdimas.v5i3.4912

Widiyatun, F. \& Wahyuni, S.E. (2021). Penyuluhan pembuatan kreasi bunga dari botol Yakult dan sedotan plastik. Jurnal Abdimas, 2(1), 98-104. 